\title{
Ocorrência do gênero Conostomum Sw. (Bartramiaceae) no Brasil
}

Denilson Fernandes Peralta ${ }^{1}$

Recebido em 17/03/2011. Aceito em 21/09/2011

\begin{abstract}
RESUMO
(Ocorrência do gênero Conostomum Sw. (Bartramiaceae) no Brasil). Esta é a primeira ocorrência do gênero Conostomum para o Brasil, detectado durante a revisão de material do herbário SP para estudo de Bartramiaceae. A espécie Conostomum macrotheca Herz. está amplamente distribuída nas áreas frias e de altitude do globo. Esta planta apresenta gametófitos pequenos e é diferenciada das demais espécies da família ocorrentes no Brasil pelos filídios dispostos em 3-4 fileiras.
\end{abstract}

Palavras-chave: musgo, novo recorde, Mata Atlântica

\begin{abstract}
(New record of the genus Conostomum Sw. (Bartramiaceae) for Brazil). This is the first citation of the genus Conostomum for Brazil, found during a revision of specimens at SP while studying the Bartramiaceae. Conostomum macrotheca Herz. is widespread in cold and high-elevation areas of the globe. This species is small and can be differentiated from other Brazilian species of the family by its 3 -4-ranked leaves.
\end{abstract}

Key words: moss, new record, Atlantic Forest

O gênero Conostomum Sw. é amplamente distribuído nas áreas frias e de altitude do globo (Frahm et al. 1996). Na revisão deste gênero foram reconhecidas 15 espécies , mas não foram analisadas amostras brasileiras (Frahm et al. 1996). Desta maneira, a ocorrência deste gênero permaneceu desconhecida e acreditava-se não ocorrer no Brasil.

Durante uma revisão de amostras depositadas no herbário SP para o estudo de Bartramiaceae, foi encontrada uma espécie deste gênero, que é nova ocorrência para o país.

Conostomum macrotheca Herz., Biblith. Bot. 87: 95. 1916.

Tipo: Bolívia, "auf Tofboden na den Cerros de Málaga,

ca. 4000 m” Herzog 4419 (Holotipo JE).

Figura 1.

Gametófitos pequenos, firmes, formando densos tufos, escuros, verde avermelhados a verde escuros. Caulídios eretos, irregularmente ramificados, ramificações na maioria curtas, densamente tomentosos na porção basal, secção transversal não apresentando banda central de estereídes.
Filídios lanceolados, em 3-4 fileiras distintas, ápice agudo a apiculado, margem denticulada apenas no ápice; costa larga, ocupando $1 / 2$ ou $3 / 4$ da larg. do filídio; células longohexagonais, com uma papila distal pouco distinta, parede celular espessada. Periquécio terminal, filídios similares aos do caulídio. Seta longa. Cápsula pendula, globosa, estriada e enrugada quando seca. Opérculo ausente. Peristômio simples, dentes lisos.

Material examidado: BRASIL: Rio de Janeiro. Parque Nacional do Itatiaia, Vital 1603 (SP).

Os gametófitos foram encontrados em solo em campo de altitude, entre 2000-2500 m de altitude. Esta espécie era conhecida apenas para a Bolívia (Frahm et al. 1996). Esta é a primeira ocorrência do gênero Conostomum para o Brasil.

De acordo com a revisão de Frahm et al. (1996) esta espécie, assim como Conostomum magellanicum Sull., possui a costa terminando abaixo do ápice. Entretanto,

\footnotetext{
${ }^{1}$ Instituto de Botânica, São Paulo, SP, Brasil 
em C. magellanicum o ápice é obtuso, a margem do ápice é inteira e as células isodiamétricas, enquanto $C$. macrotheca possui o ápice apiculado, margem do ápice com inúmeros dentes e células longo lineares (4-10:1).

\section{Referências bigliográficas}

Frahm, J.-P., Börner, H., Streiber, N., Wallau, B., Weitkus, S. 1996. Revision der Gattung Conostomum (Musci, Bartramiaceae). Tropical Bryology 12: $97-114$.

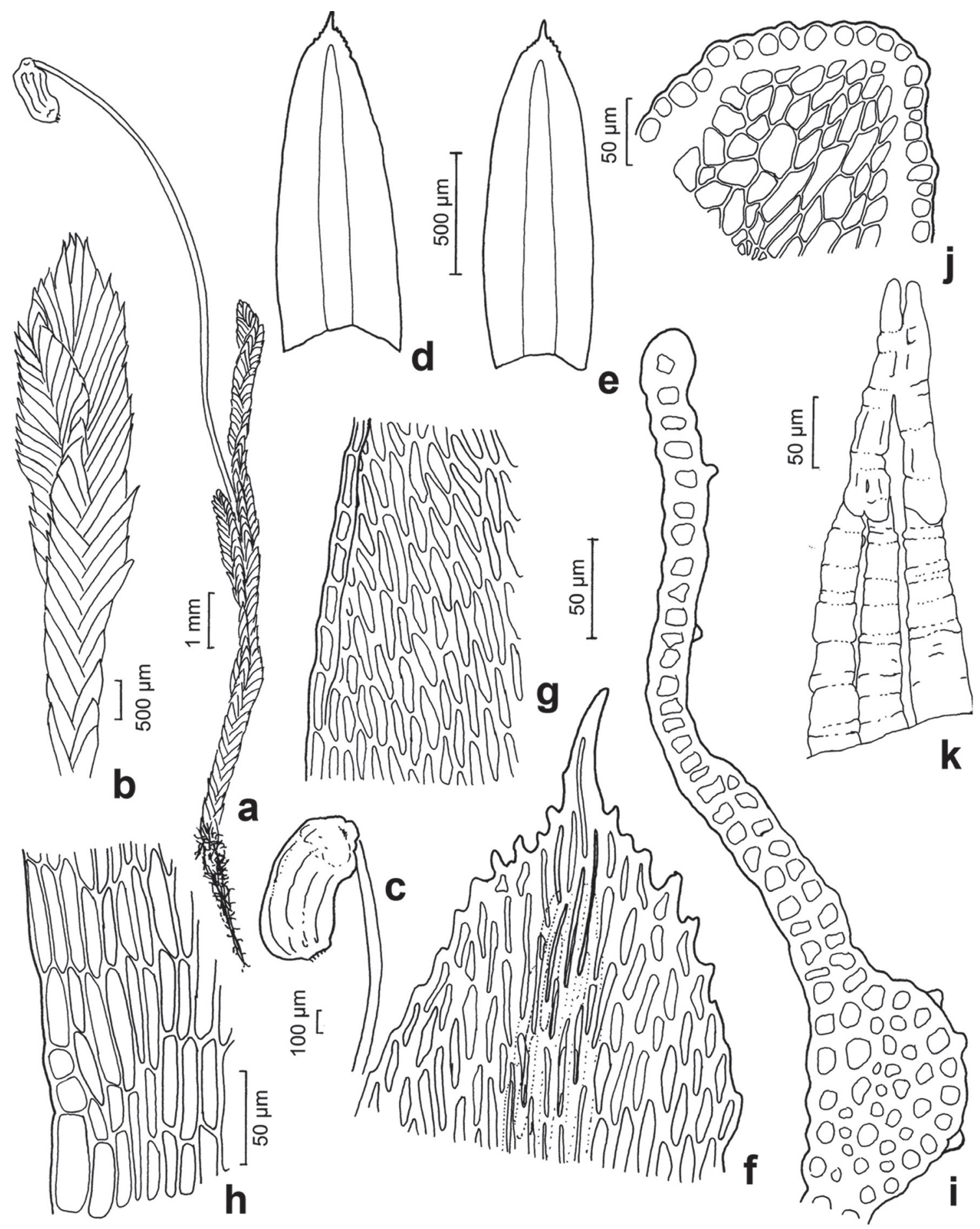

Figura 1. Conostomum macrotheca Herz. a. hábito, b. detalhe do arranjo dos filídios, c. detalhe da cápsula, d-e. filídios, f. células do ápice do filídio, g. células da lâmina do filídio, h. células da base do filídio, i. seção transversal na região mediana do filídio, j. secção transversal do caulídio, k. dentes do peristômio. 